Société d'histoire de la révolution de 1848 et des

révolutions du XIXe siècle

$5 \mid 1989$

Histoires de centenaires, ou le devenir des révolutions

\title{
Liberté et unité : le mariage impossible sur le centenaire de "1848" en Allemagne
}

\section{Rainer Riemenschneider}

\section{OpenEdition}

\section{Journals}

Electronic version

URL: http://journals.openedition.org/rh19/36

DOI: $10.4000 /$ rh 19.36

ISSN: $1777-5329$

\section{Publisher}

La Société de 1848

\section{Printed version}

Date of publication: 1 June 1989

ISSN: 1265-1354

Electronic reference

Rainer Riemenschneider, "Liberté et unité : le mariage impossible sur le centenaire de "1848" en Allemagne », Revue d'histoire du XIXe siècle [Online], 5 | 1989, Online since 09 September 2008, connection on 01 May 2019. URL : http://journals.openedition.org/rh19/36 ; DOI : 10.4000/rh19.36

This text was automatically generated on 1 May 2019.

Tous droits réservés 


\section{Liberté et unité : le mariage impossible} sur le centenaire de "1848" en Allemagne

Rainer Riemenschneider

\section{ABSTRACTS}

No abstract available by now

Pas de résumé disponible actuellement

INDEX

Mots-clés: Commémoration, Mémoire 